\title{
MENGELOLA LAPORAN KEUANGAN PARA PELAKU USAHA PADA PKBM BINA MANDIRI BANDUNG
}

\author{
Dini Wahjoe Hapsari*1, Dudi Pratomo ${ }^{2}$, Elly Suryani ${ }^{3}$ \\ ${ }^{1,2,3}$ Program Studi S1 Akuntansi, Fakultas Ekonomi dan Bisnis, Telkom University \\ Telkom University; Jalan Telekomunikasi No. 1 Bandung, telp (022) 7564108 \\ *E-mail : dinihapsari@telkomuniversity.ac.id
}

\begin{abstract}
Every business people is required to make a financial report which is the accountability report of his business activities. Including a newly business people. They are required to prepare financial statements without being trapped in the complexity of the applicable accounting standards. These business people can arrange financial statements simply as long as they do not deviate from the applicable standards. To be able to manage financial statements, at the beginning of this business people must know the type of business, opportunities and challenges in the business world. When they understand their business position, they must make an analysis so that their business runs well. After finding new positions and business opportunities, business people can determine strategies in making financial statements so they are easy to use. Many business people today have not done business analysis and bookkeeping properly, so they do not have the required financial statements. This is due to the lack of understanding of business people how to manage financial reports in the business they are running. This community service activity provides training for business people at the Bina Mandiri Community Learning Center (PKBM) located on Jalan Tubagus Ismail No. 27 Bandung. The method used is to provide material, questions and answers and discussions that discuss the problems faced and suggestions for solutions. Provide financial report templates that can be used by participants. The activity was ended by filling out a questionnaire related to the activity which was the feedback of the activity. Based on the results of the questionnaire, it can be seen the achievements of the activities and expectations of the participants in the future. Training on the management of financial statements is very beneficial for participants, they become more aware of the importance of preparing financial reports and the function of financial statements. Participants hope there will be more training with different material tailored to the problems expressed.
\end{abstract}

Keywords-PKBM, financial statement

\begin{abstract}
Abstrak
Setiap pelaku usaha diwajibkan untuk membuat laporan keuangan yang merupakan laporan pertanggung jawaban aktivitas bisnisnya. Termasuk pelaku usaha yang baru didirikan atau mereka sudah ada tapi umurnya masih pendek. Mereka diwajibkan menyusun laporan keuangan tanpa terjebak kerumitan standar akuntansi yang berlaku. Para pelaku usaha ini dapat menyusun laporan keuangan dengan sederhana selama tidak menyimpang dari standar yang berlaku. Untuk dapat mengelola laporan keuangan dengan baik, di saat awal para pelaku usaha ini harus mengetahui jenis bisnisnya, peluang dan tantangan di dunia bisnis. Apabila sudah memahami posisi bisnisnya mereka harus membuat analisis agar bisnis mereka berjalan dengan baik. Setelah menemukan posisi dan peluang bisnisnya baru pelaku usaha dapat menentukan strategi dalam membuat laporan keuangan agar mudah digunakan. Para pelaku usaha saat ini banyak yang belum melakukan analisis bisnis dan pembukuan secara baik, sehingga mereka tidak memiliki laporan keuangan yang dibutuhkan. Hal ini disebabkan belum pahamnya para pelaku usaha bagaimana mengelola laporan keuangan pada bisnis yang dijalankan. Kegiatan pengabdian masyarakat ini memberikan pelatihan bagi para pelaku usaha pada Pusat Kegiatan Belajar Masyarakat (PKBM) Bina Mandiri yang berlokasi di Jalan Tubagus Ismail No. 27 Bandung. Metode yang digunakan adalah memberikan materi, tanya-jawab dan diskusi yang membahas permasalahan yang dihadapi serta saran untuk solusi. Memberikan template laporan keuangan yang dapat digunakan oleh peserta. Kegiatan diakhiri dengan mengisi kuesioner terkait kegiatan
\end{abstract}


yang menjadi umpan balik kegiatan. Berdasar hasil kuesioner dapat dilihat pencapaian kegiatan dan harapan peserta di masa yang akan datang. Pelatihan mengenai pengelolaan laporan keuangan sangat bermanfaat bagi peserta, mereka menjadi lebih paham pentingnya penyusunan laporan keuangan serta fungsi laporan keuangan. Peserta berharap akan ada pelatihan lagi dengan materi yang berbeda disesuaikan dengan masalah yang diungkapkan.

Kata kunci-PKBM, Laporan Keuangan

\section{PENDAHULUAN}

Pusat Kegiatan Belajar Masyarakat (PKBM) adalah lembaga yang dibentuk oleh masyarakat untuk masyarakat yang bergerak dalam bidang pendidikan. PKBM ini masih berada di bawah pengawasan dan bimbingan dari Dinas Pendidikan Nasional. PKBM ini bisa berupa tingkat desa ataupun kecamatan. Tujuan PKBM, memperluas kesempatan warga masyarakat, khususnya yang tidak mampu untuk meningkatkan pengetahuan, keterampilan dan sikap mental yang diperlukan untuk mengembangkan diri dan bekerja mencari nafkah. Sehingga prinsip dari PKBM adalah : dari masyarakat, oleh masyarakat dan untuk masyarakat. Undang-Undang No. 20 Tahun 2003 Tentang Sistem Pendidikan Nasional mengakui bahwa PKBM adalah Satuan Pendidikan Non Formal [5]. Hal ini sama seperti diakuinya Sekolah adalah Satuan Pendidikan Formal.

Program-program yang diselenggarakan di PKBM sangat beragam dan dapat tidak terbatas, tapi disesuaikan dengan kondisi, potensi dan kebutuhan masyarakat di mana PKBM itu berada. Kegiatan dari PKBM dapat dibagi 2 yaitu : kegiatan pembelajaran dan kegiatan non pembelajaran. Dapat dilihat pada gambar berikut :

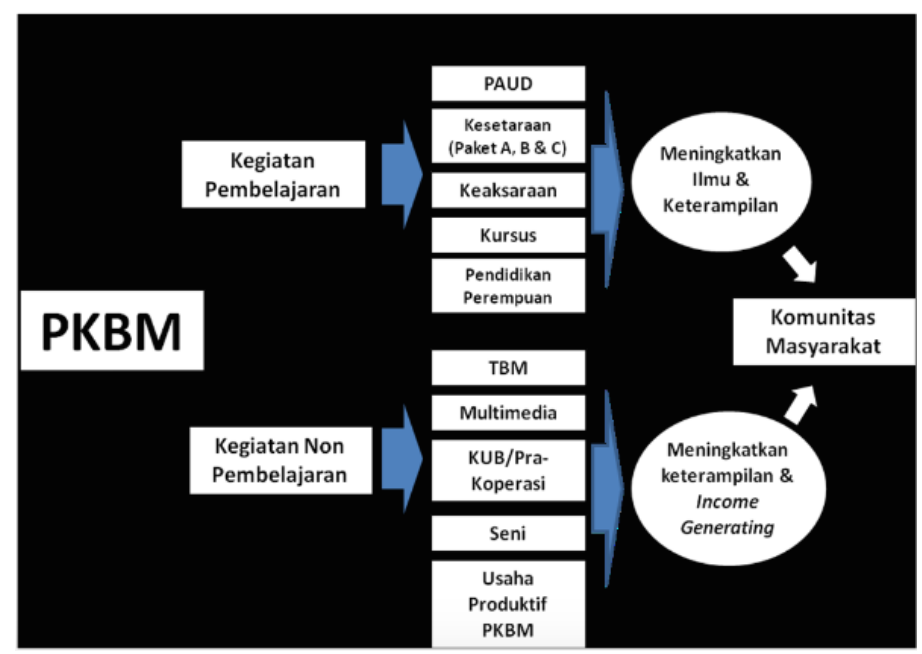

Sumber : staffnew.uny.ac.id

Gambar 1. Bagan Kegiatan PKBM

Berdasar gambar di atas dapat disimpulkan bidang kegiatan dalam PKBM adalah pendidikan, wirausaha dan pemasaran serta kemitraan dan informasi. Tujuan dari kegiatan-kegiatan ini adalah meningkatkan ketrampilan untuk menunjang peningkatan pendapatan masyarakat setempat. Program-program yang dapat dilakukan PKBM umumnya antara lain :

1. Pendidikan Kesetaraan : Paket A, Paket B dan Paket C.

2. Pendidikan Keaksaraan Fungsional/KF (bagi Buta Aksara)

3. Taman Bacaan Masyarakat (TBM)

4. Pendidikan Keterampilan, Kecakapan Hidup (life skill) dan Kursus-kursus.

5. Pendidikan Kewirausahaan, Usaha Produktif Masyarakat, Kelompok Belajar Usaha (KBU dan KUBE).

6. Pendidikan Lingkungan Hidup, Pelestarian Hutan, Penyuluhan Pertanian, Peternakan dan Perikanan.

7. Pendidikan Kesehatan Masyarakat. 
Dari program-program yang diadakan oleh PKBM terdapat satu Pendidikan yang tengah digalakkan oleh pemerintah, yaitu Pendidikan Kewirausahaan, Usaha Produktif Masyarakat dan Kelompok Belajar Usaha adalah program yang ditujukan untuk meningkatkan kesejahteraan masyarakat melalui usaha/bisnis masyarakat baik dilakukan secara berkelompok atau bersamasama. Selain itu juga sebagai sumber pembiayaan bagi keberlangsungan lembaga atau programprogram lainnya. Keberhasilan program ini akan makin meningkatkan semangat masyarakat untuk terus belajar dan berkembang.

Masyarakat Sasar pada kegiatan pengabdian masyarakat ini adalah para pelaku usaha yang ada pada Pusat Kegiatan Belajar Masyarakat Bina Mandiri Center yang berlokasi di Jalan Tubagus Ismail No. 27, Bandung. Peta lokasi PKBM terlihat pada Gambar 2 berikut :

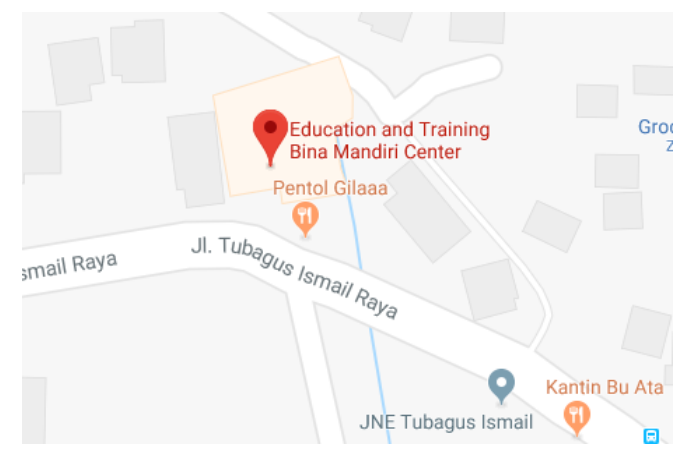

Gambar 2. Lokasi PKBM Bina Mandiri Center

Berawal merintis sebuah lembaga pendidikan yang bergerak dalam bidang pendidikan dengan nama PKBM (Pusat Kegiatan Belajar Masyarakat) yang diberi nama PKBM Bina Mandiri Center dengan tagline melayani yang tak terlayani dan menjangkau yang tak terjangkau artinya melayani warga belajar yang tak bisa menjangkau karena tempat dan biaya pendidikan yang mahal. PKBM ini didirikan dengan tujuan membantu pemerintah dalam mencerdaskan kehidupan bangsa melalui Pendidikan non formal yaitu memberikan pelatihan-pelatihan bagi para pelaku usaha.

PKBM Bina Mandiri Center Bandung merupakan salah satu lembaga pendidikan mitra pemerintah kota bandung yang telah 10 tahun meluluskan 3000 alumni serta menjalin kemitraan dengan pengguna lulusan dunia usaha dan industri, serta kerjasama dengan pemerintah Kota Bandung dalam penanganan program PIPPK Tahun 2015. Salah satu program PIPPK yang pernah diselenggarakan adalah Pelatihan Kewirausahaan bagi warga masyarakat Kelurahan Dago Kota Bandung. Pelaksanaan pelatihan ini membahas bagaimana membuka dunia usaha serta bagaimana memasarkan usaha tersebut. Dalam pelatihan ini peserta banyak mengalami permasalahan dalam pengelolaan laporan keuangan bagi pelaku usaha baru. Sehingga perlu dilakukan sebuah pelatihan tentang pengelolaan keuangan bagi para pelaku usaha guna mendukung bisnis yang dijalankan.

Menurut Kieso et. All (2014:5) "The financial statement most frequently provided are (1) the statement of financial statements position, (2) the income statement or statement of comprehensive income, (3) the statement of cash flows, and (4) the statement of changes in equity. Note disclosures are an integral part of each financial statement" [3]

Laporan keuangan adalah suatu penyajian terstruktur dari posisi keuangan dan kinerja keuangan suatu entitas. Tujuan laporan keuangan adalah memberikan informasi mengenai posisi keuangan, kinerja keuangan, dan arus kas entitas yang bermanfaat bagi sebagian besar pengguna laporan keuangan dalam pembuatan keputusan ekonomik [1].

Secara sederhana dapat dikatakan setiap pelaku usaha baik pemula dianjurkan untuk membuat laporan keuangan. Fungsinya adalah untuk mengetahui berapa modal yang sudah disertakan, berapa besar pendapatan dan pengeluaran serta apakah usaha yang dirintis masih mengalami kerugian atau sudah mengalami keuntungan. Apabila mengalami keuntungan berapa besar keuntungan yang sudah diperoleh.

Para Pelaku Usaha harus membuat laporan keuangan sebagai bentuk pertanggung jawaban aktivitas yang dilaksanakan. Mereka menemukan beberapa permasalahan, yaitu :

1. Para pelaku usaha belum memahami persaingan dalam dunia bisnis, mereka baru dapat mendirikan suatu usaha saja tanpa memahami resiko yang akan dihadapi. 
2. Para pelaku usaha belum memahami pencatatan dari transaksi

3. Para pelaku usaha masih belum memahami bagaimana membuat laporan keuangan yang benar.

4. Para pelaku usaha belum memahami mengelola laporan keuangan yang baik.

Potensi atau peluang dari pemberdayaan masyarakat sasar adalah apabila mereka telah mampu melakukan pengelolaan keuangan dengan baik mereka akan menjadi pelaku usaha yang besar. Dengan berkembangnya pelaku usaha maka kegiatan bisnis di lingkungan tersebut semakin hidup dan dapat membantu mengurangi angka pengangguran.

Berdasar permasalahan yang dihadapi dan potensi pemberdayaan masyarakat sasar, dalam kegiatan pengabdian masyarakat ini akan dilakukan kegiatan/pelatihan mengenai : (1) memahami bisnis usaha, (2) mengenal transaksi dan pencatatan transaksi, (3) mengenal akun-akun yang wajib digunakan, dan (4) mengelola laporan keuangan.

\section{METODE}

Bentuk kegiatan berupa pelatihan mengenai mengelola laporan keuangan. Untuk lebih memahami kebutuhan dari masyarakat sasar, di awal dilakukan diskusi dengan seluruh peserta yang bertujuan lebih memahami kebutuhan peserta. Selanjutnya baru masuk pada pemberian materi Materi yang akan disampaikan dapat dilihat dalam tabel berikut :

Tabel 1. Ringkasan Materi

\begin{tabular}{|c|c|c|c|}
\hline No & Modul & Tujuan & Materi \\
\hline 1 & Pengenalan Bisnis & $\begin{array}{l}\text { Mengenalkan bisnis dan } \\
\text { peluang bisnis untuk } \\
\text { pemula. }\end{array}$ & $\begin{array}{l}\text { Bisnis dan peluang bisnis, melakukan } \\
\text { SWOT analysis }\end{array}$ \\
\hline 2 & $\begin{array}{l}\text { Pengenalan } \\
\text { Transaksi serta } \\
\text { Pencatatan }\end{array}$ & $\begin{array}{l}\text { Memahami transaksi dan } \\
\text { melakukan pencatatan serta } \\
\text { memahami prinsip } \\
\text { pembuatan jurnal. }\end{array}$ & Jurnal dan Buku Besar \\
\hline 3 & $\begin{array}{l}\text { Penyelesaian } \\
\text { Laporan Keuangan }\end{array}$ & $\begin{array}{l}\text { Menyusun Laporan } \\
\text { Keuangan }\end{array}$ & $\begin{array}{l}\text { Laporan Laba Rugi, Laporan Posisi } \\
\text { Keuangan dan Laporan Arus Kas }\end{array}$ \\
\hline 4 & $\begin{array}{l}\text { Mengelola } \\
\text { Laporan Keuangan }\end{array}$ & $\begin{array}{l}\text { Mampu menyusun laporan } \\
\text { keuangan sederhana serta } \\
\text { melakukan perhitungan } \\
\text { laba dari bisnis usaha. }\end{array}$ & Rasio Keuangan \\
\hline
\end{tabular}

\section{HASIL DAN PEMBAHASAN}

Lokasi kegiatan pengabdian masyarakat adalah PKBM Bina Mandiri Center yang berlokasi di Jalan Tubagus Ismail No. 27 Bandung. Kegiatan Pengabdian Masyarakat ini diikuti oleh 29 pelaku usaha yang sering mengikuti pelatihan yang diadakan oleh PKBM. Pelaksanaan kegiatan dilaksanakan di Ruang Serba Guna PKBM.

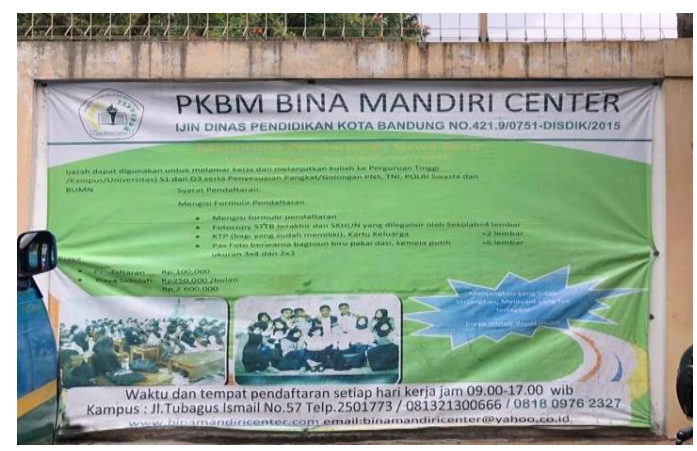

Gambar 3. PKBM Bina Mandiri Center 
Rangkaian kegiatan diawali dengan diskusi mengenai permasalahan yang dihadapai oleh pelaku usaha. Permasalahan yang dihadapi adalah :

(1) Minimnya modal yang dimiliki sehingga tidak mampu meneruskan usaha dalam jangka panjang. Hal ini mengakibatkan mereka harus berganti jenis usaha yang dinilai membutuhkan modal yang tidak terlalu besar. Mengganti usaha berarti memulai lagi dari awal sehingga sulit mengukur keberhasilan usaha.

(2) Ketidakmampuan mengajukan dana ke pihak ke-3 seperti Bank. Karena bank selalu meminta Analisa SWOT dan laporan keuangan dalam pengajuan dana.

(3) Dalam menjalankan usaha, para pelaku usaha belum mampu membuat keuangan yang menggambarkan kondisi usahanya apakah masih rugi, sudah untung atau keberlanjutan usahanya.

(4) Belum pahamnya pengetahuan perpajakan dari objek pajak sampai perhitungan perpajakan dari setiap transaksi yang muncul. Untuk permasalahan ke-4 tidak termasuk dalam materi kegiatan pengabdian masyarakat, materi ini akan disampaikan pada kegiatan selanjutnya.

Kegiatan dilanjutkan dengan pemberian materi berupa pengenalan bisnis dimana kami mengenalkan jenis-jenis usaha. Mengelompokkan kegiatan bisnis mereka masuk ke kategori jenis usaha yang mana, belajar membuat SWOT dengan melihat kekuatan dan bisnis yang dilaksanakan sehingga berani mencoba usaha tersebut, kelemahan yang dimiliki, kesempatan ke depan dari bisnis yang dilaksanakan serta ancaman dari pesaing atas bisnis yang dijalankan. Setelah mereka mampu menganalisis secara sederhana bisnis usahanya, materi dilanjutkan dengan pengelolaan keuangan yang dimulai dengan pengenalan transaksi serta akun-akun yang wajib diketahui. Menyelesaikan laporan keuangan serta membuat perhitungan profitabilitas terkait dengan bisnis yang dijalankan.

Setelah penyampaian materi, kami memberikan kuesioner terkait kegiatan pengabdian masyarakat. Kami mencoba melihat feed-back langsung melalui kuesioner ini. Ternyata antusiasme mereka cukup besar yaitu menjawab pertanyaan dengan semangat.Setelah seluruh rangkaian acara selesai, para peserta diberikan sertifikat. Bukti mereka telah mengikuti kegiatan workshop. Berikut foto-foto selama kegiatan :

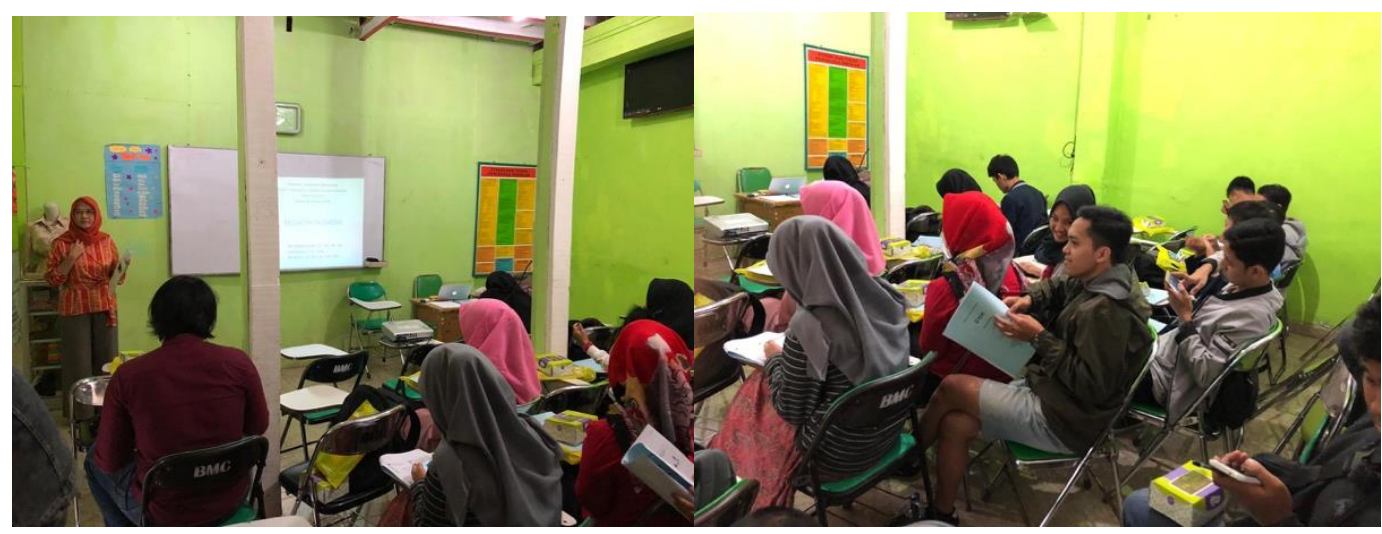

Gambar 4. Suasana Kegiatan di PKBM Bina Mandiri Center 


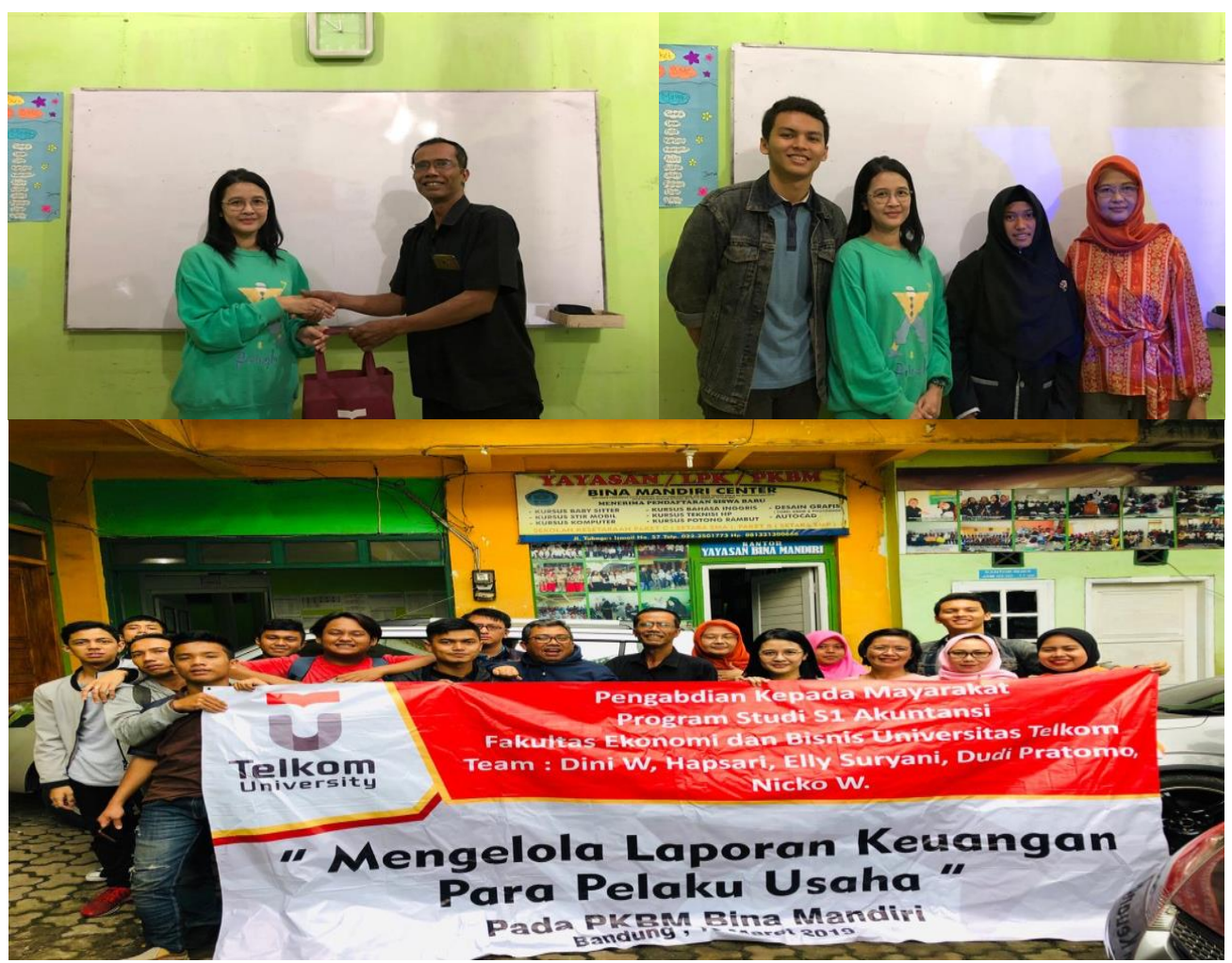

Gambar 5. Tim Pengabdian Masyarakat Telkom University Bersama Peserta PKBM Bina Mandiri Center

\section{Feedback Kegiatan}

Feedback secara kualitatif dilakukan dengan evaluasi melalui kuesioner yang dibagikan setelah pelaksanaan kegiatan yang diisi oleh peserta sebagai masyarakat sasar, hasil kuesioner kepuasan terhadap pelaksanaan kegiatan pengabdian masyarakat ini. Adapun pertanyaannya meliputi 1) Kesesuaian kegiatan dengan tujuan kegiatan, 2) Program kegiatan sudah sesuai dengan kebutuhan para UMKM, 3) Waktu pelaksanaan program kegiatan ini relatif telah mencukupi sesuai kebutuhan, 4) Dosen dan mahasiswa Universitas Telkom bersikap ramah, cepat dan tanggap membantu selama kegiatan, 5) Masyarakat setempat menerima dan mengharapkan program pengabdian masyarakat Universitas Telkom saat ini dan masa yang akan datang. Hasil dari kuesioner tergambar sebagai berikut:

1. Kesesuaian kegiatan abdimas

Berdasar hasil kuesioner yang diisi oleh peserta workshop diperoleh $30 \%$ sangat setuju dan $70 \%$ setuju kegiatan ini sesuai dengan tujuan yaitu materi mengelola laporan keuangan pelaku usaha. Berikut chart tanggapan dari para peserta Pelaku Usaha :

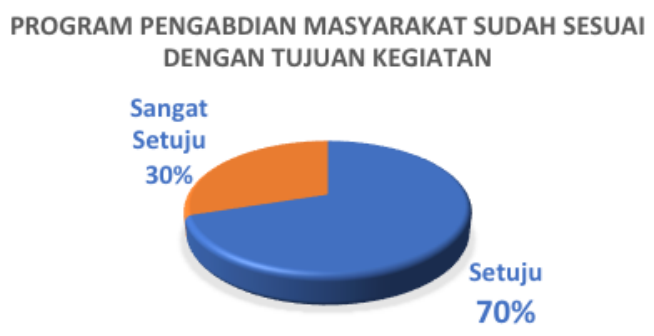

Gambar 6. Tanggapan Kuesioner 1

2. Program Kegiatan Telah Sesuai Dengan Kebutuhan Para Pelaku Usaha

Berdasar hasil kuesioner yang diisi oleh peserta workshop diperoleh $47 \%$ sangat setuju dan 53\% setuju kegiatan ini sesuai dengan kebutuhan yaitu materi mengelola laporan keuangan 
telah sesuai kebutuhan pelaku usaha. Berikut chart tanggapan dari para peserta Pelaku Usaha :

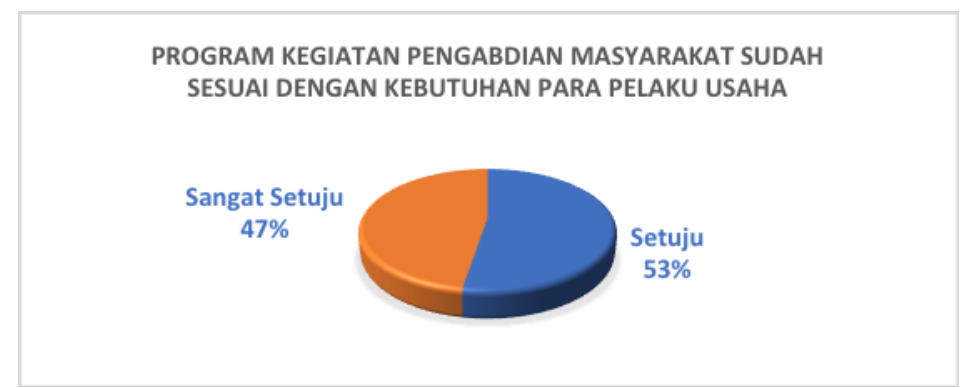

Gambar 7. Tanggapan Kuesioner 2

3. Waktu pelaksanaan sesuai dengan kebutuhan Para Pelaku Usaha Berdasar hasil kuesioner yang diisi oleh peserta workshop diperoleh $30 \%$ sangat setuju dan $70 \%$ setuju waktu pelaksanaan seminar relative telah mencukupi kebutuhan para pelaku usaha. Berikut chart tanggapan dari para peserta Pelaku Usaha :

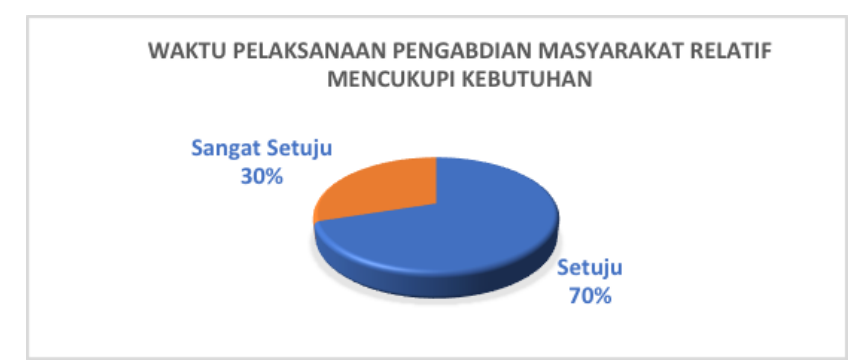

Gambar 8. Tanggapan Kuesioner 3

4. Dosen dan Mahasiswa Bersikap Ramah, Cepat dan Tanggap Membantu

Berdasar hasil kuesioner yang diisi oleh peserta workshop diperoleh $65 \%$ sangat setuju dan $35 \%$ setuju waktu pelaksanaan seminar relatif telah mencukupi kebutuhan para pelaku usaha. Berikut chart tanggapan dari para peserta Pelaku Usaha :

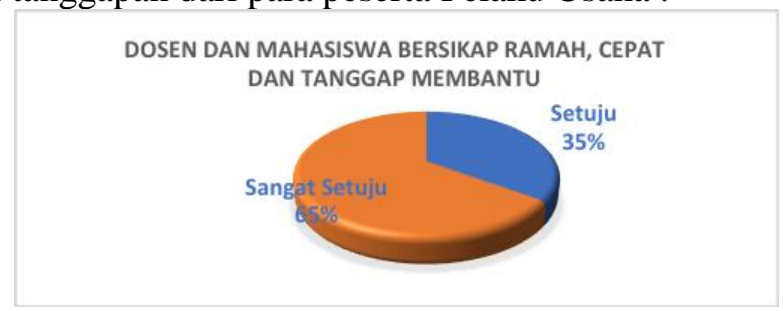

Gambar 9. Tanggapan Kuesioner 4

5. Para UMKM berharap ada kegiatan kelanjutan di masa mendatang

Berdasar hasil kuesioner yang diisi oleh peserta workshop diperoleh $70 \%$ sangat setuju dan $30 \%$ setuju waktu pelaksanaan seminar relatif telah mencukupi kebutuhan para pelaku usaha. Berikut chart tanggapan dari para peserta Pelaku Usaha :

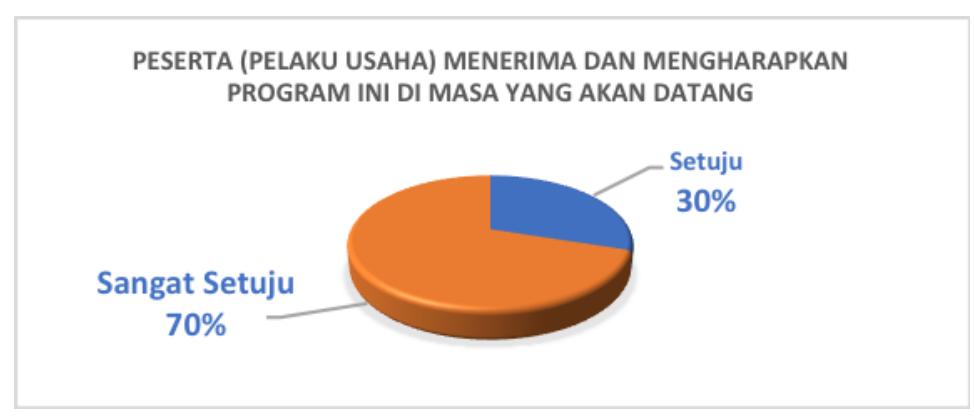

Gambar 10. Tanggapan Kuesioner 5 


\section{KESIMPULAN}

Workshop mengelola laporan keuangan untuk para pelaku usaha pada PKBM Bina Mandiri Center disambut baik oleh para peserta. Peserta memperoleh ilmu baru untuk dapat diterapkan dalam bisnis usahanya. Adapaun hasil yang diperoleh :

1. Permasalahan pelaku usaha yang belum memahami bagaimana menjalankan bisnisnya. Memanfaatkan kekuatan dan peluang, menutupi kekurangan serta antisipasi ancaman dari luar. Berdasar permasalahan yang ada mencoba membuat SWOT secara sederhana.

2. Para pelaku usaha harus memahami setiap transaksi dari kegiatan bisnisnya, mampu mengelompokkan dan menentukan akun untuk melakukan pencatatan sampai dengan menyusun laporan keuangan.

3. Setelah memiliki laporan keuangan, para pelaku usaha juga harus mampu memanfaatkannya dengan mengajukan dana kepada pihak ke-3 apabila membutuhkan dana untuk pengembangan usaha.

4. Permasalahan lain yang dihadapi adalah belum pahamnya transaksi apa saja yang termasuk objek pajak beserta bagaimana perhitungan perpajakan.

\section{SARAN}

Saran untuk kegiatan pengabdian lebih lanjut adalah memberikan materi khusus untuk perhitungan yang diperlukan apabila para pelaku usaha akan mengajukan kredit/dana kepada pihak ke-3. Hal lain para pelaku usaha juga membutuhkan pelatihan mengenai perpajakan beserta perhitungan pajak.

\section{UCAPAN TERIMA KASIH}

Tim pengabdian masyarakat di PKBM Bina Mandiri Center mengucapkan terima kasih kepada Telkom University yang telah memberi dukungan financial terhadap kegiatan pengabdian masyarakat ini.

\section{DAFTAR PUSTAKA}

[1] Ikatan Akuntan Indonesia. 2016. Standar Akuntansi Keuangan per 1 Juli 2017. Jakarta : Salemba Empat

[2] Ikatan Akuntantan Indonesia, 2016. Standar Akuntansi Keuangan Enitas Mikro Kecil dan Menengah per 1 Januari 2018, Jakarta : Salemba Empat

[3] Kieso, D.D., Weygandt, J. J., Warfield, T.D. 2014. Intermediate Accounting, IFRS Edition, 2nd ed., Hoboken, New Jersey: John Wiley \& Sons

[4] Martani, Dwi et all. 2016. Akuntansi Keuangan 1, Jakarta, Salemba Empat

[5] Undang-Undang Republik Indonesia No. 20 Tahun 2003 Tentang Sistem Pendidikan Nasional 